\title{
The use of regeneration profiles as a tool to optimise the performance of demineralisation water treatment plants
}

\author{
Casper JH du P Strydom* and C Frederik Schutte \\ Water Utilisation Division, Department of Chemical Engineering, University of Pretoria, South Africa
}

\begin{abstract}
Demineralised water is used as make-up water to compensate for losses in the condensate-boiler feed-water stream at power stations and other steam raising plants. Demineralisation plants are designed to produce pure water that contains virtually no impurities. Ion exchange is invariably used for demineralisation. Effective regeneration of exhausted resin is an important aspect to ensure optimal performance of the ion exchange process. Regeneration profiles were used in this investigation to determine the effectiveness of regeneration and to optimise the regeneration process.
\end{abstract}

Keywords: demineralisation, regeneration profiles, optimised regeneration

\section{Introduction}

The make-up water for modern high-pressure fossil-fuelled boilers has to be of extremely high quality with virtually complete removal of salts and gases. Impure water may cause failure of a turbine or boiler that will result in large financial losses amounting to millions of Rand per day. The make-up water quality depends on the design and unit operations incorporated in a treatment system. A number of processes may be used in the pretreatment of raw water, but invariably the final stage is an ion-exchange demineralisation process (Modern Power Station Practice, 1992; Drew, 1994). This article focuses on the use of regeneration profiles to optimise ionexchange regeneration and to increase run lengths, thereby reducing water production costs.

\section{Boiler make-up quality}

Boiler make-up water is the product water from a demineralisation plant that is fed into the boiler drum to compensate for water losses. The quality of the boiler make-up water determines the boiler operating efficiency (Harfst, 1993). The Eskom chemistry standard for make-up water for drum boilers operating at $17 \mathrm{MPa}$ and above is listed in Table 1.

\section{lon-exchange process}

Ion exchange is a process whereby pretreated water is stripped from unwanted cations and anions to give a product water of specific quality. Ion exchange comprises the reversible exchange of ions between a solid (resin) and a liquid in which there is no substantial change in the structure of the solid. At the start of a service cycle the predominant ionic form of the resins is either the hydrogen (cation) or hydroxyl (anion) form. The hydrogen and hydroxyl ions are exchanged respectively for unwanted cations and anions in the feed water. Exhausted resins are regenerated with a highly concen-

\footnotetext{
* To whom all correspondence should be addressed.

I

e-mail: StrydoCJ@eskom.co.za

Received 7 February 2003; accepted in revised form 8 July 2003.
}

\begin{tabular}{|l|c|c|}
\hline \multicolumn{3}{|c|}{ TABLE 1 } \\
Recommended water quality limits for boiler \\
make-up water \\
\hline Parameter & Units & Limit \\
\hline Turbidity & $(\mathrm{NTU})$ & 0.2 \\
Specific conductivity $\left(25^{\circ} \mathrm{C}\right)$ & $(\mu \mathrm{S} / \mathrm{cm})$ & 0.1 \\
Sodium (as $\left.\mathrm{Na}^{+}\right)$ & $(\mu \mathrm{g} / \mathrm{kg})$ & 2 \\
Silica (as $\left.\mathrm{SiO}_{2}\right)$ & $(\mu \mathrm{g} / \mathrm{kg})$ & 10 \\
Chloride $\left(\right.$ as $\left.\mathrm{Cl}^{-}\right)$ & $(\mu \mathrm{g} / \mathrm{kg})$ & 2 \\
Sulphate (as $\left.\mathrm{SO}_{4}{ }^{2-}\right)$ & $(\mu \mathrm{g} / \mathrm{kg})$ & 2 \\
TOC (as C) & $(\mu \mathrm{g} / \mathrm{kg})$ & 300 \\
\hline Source: Eskom, 2001 & \\
\hline
\end{tabular}

trated regenerant solution, restoring the resin bed to the ionic form that is again useful to the process (Frederick, 1996).

\section{Demineralisation consists of the following steps:}

\section{Cation exchange}

The cation exchanger contains two types of cation resins, namely strong-acid exchange resins (SAC) and weak-acid exchange resins (WAC). The SAC can split neutral salts, i.e. remove non-carbonate hardness, while WAC can only remove carbonate hardness from the water. On exhaustion the resins are restored to the original state by regenerating the WAC downwards with a 0.8 to $1.5 \% \mathrm{H}_{2} \mathrm{SO}_{4}$ solution, while the $\mathrm{SAC}$ is regenerated upwards with a $5 \% \mathrm{H}_{2} \mathrm{SO}_{4}$ solution.

\section{Degasification}

The raw water entering the cation exchangers contains alkalinity (bicarbonate and carbonate ions) that decomposes into carbon dioxide $\left(\mathrm{CO}_{2}\right)$ and water. Forced draft degasifiers are used to remove the $\mathrm{CO}_{2}$ to reduce the load on the anion exchanger (Meyers, 1996). 


\begin{tabular}{|c|c|c|c|c|c|}
\hline \multicolumn{6}{|c|}{$\begin{array}{c}\text { TABLE } 2 \\
\text { Regeneration procedure applied at Matla Power Station }\end{array}$} \\
\hline \multicolumn{3}{|c|}{ Cation unit } & \multicolumn{3}{|c|}{ Anion unit } \\
\hline Step & Step description & $\begin{array}{l}\text { Duration } \\
\text { (min) }\end{array}$ & Step & Step description & $\begin{array}{l}\text { Duration } \\
\text { (min) }\end{array}$ \\
\hline 01 & Backwash top & 8 & $01(\mathrm{a})$ & Backwash weak base & 8 \\
\hline 02 & Settle & 2 & $02(a)$ & Drain weak base & 15 \\
\hline 03 & Forced settle & 4 & 01(b) & Drain strong base & 15 \\
\hline 04 & Establish flows & 3 & 02(b) & Pre-injection strong base & \\
\hline 05(a) & $\begin{array}{l}0.5 / 2.0 \% \text { acid injection - } \\
\text { top and bottom }\end{array}$ & 80 & 03(a) & $\begin{array}{l}4 \% \mathrm{NaOH} \text { injection } \\
\text { strong base }\end{array}$ & 50 \\
\hline 05(b) & $\begin{array}{l}0.8 / 3.0 \% \text { acid injection - } \\
\text { top and bottom }\end{array}$ & 20 & 03(b) & $\begin{array}{l}\mathrm{NaOH} \text { injection strong } \\
\text { and weak base }\end{array}$ & 30 \\
\hline 06 & Rinse top and bottom & 80 & 04 & Slow rinse/pump flush & 75 \\
\hline 07 & Downward rinse & 30 & 05 & $\begin{array}{l}\text { Fast rinse strong and } \\
\text { weak base }\end{array}$ & 45 \\
\hline \multirow[t]{4}{*}{08} & Backwash top & 3 & 06 & Drain weak base & 15 \\
\hline & & & & Refill strong base & 14 \\
\hline & & & 07 & Refill weak base & 10 \\
\hline & & & 08 & Fast rinse weak base & 20 \\
\hline
\end{tabular}

\section{Anion exchange}

The weak-base exchange resins (WBA) and strong-base exchange resins (SBA) are held in two separate exchangers. The strong-base and weak-base anion exchangers are regenerated in the upward and downward direction with $4 \% \mathrm{NaOH}$ at $49^{\circ} \mathrm{C}$ respectively. The weak-base anion exchanger is regenerated with used regenerant from the strong-base unit.

\section{Mixed bed exchanger}

The mixed bed exchanger is filled with SAC and SBA resins that "polish" the effluent of the strong-base anion exchanger. The SAC and SBA are regenerated with $6 \% \mathrm{H}_{2} \mathrm{SO}_{4}$ and $4 \% \mathrm{NaOH}$ at $49^{\circ} \mathrm{C}$ respectively.

\section{Optimisation of regeneration}

The regeneration process can be optimised by analysing concentration profiles of the different ions and substances in the regenerant streams. A regeneration profile is a valuable tool to assess the efficiency and efficacy of the different regeneration steps and the run length of the demineraliser. It is a graphical representation produced by analysing samples taken during regeneration at various time intervals. Regeneration profiles are useful as a tool to answer questions such as:

- Are the backwash steps long enough to remove all colloids?

- Are the correct acid and caustic strengths used in the injection phases?

- Are the rinse times in line with design values?

- What is the condition of the ion-exchange resins in use?

To develop a regeneration profile the following has to be done:

- Ion-exchange resin samples evaluated before and after regeneration.
- Effluent samples taken and analysed at various points in the process at different time intervals during regeneration.

- Analysis results plotted to determine trends.

Cation and anion resin regeneration can be profiled separately, plotting the various parameters analysed as a function of time.

\section{Study objectives}

The efficiency of regeneration is generally evaluated in terms of the restoration of the exchange capacity of the resins. This routine procedure does not give any specific information about the efficiency of the individual regeneration steps and inefficiencies may therefore go undetected. The purpose of this study was to evaluate the use of regeneration profiles as a tool to optimise the regeneration process.

\section{Regeneration studies}

\section{Background information}

The investigations were carried out at the demineralisation plant of the Eskom Matla Power Station. The plant consists of three parallel treatment trains, each producing a maximum flow of $220 \mathrm{~m}^{3} / \mathrm{h}$ with a total hydraulic capacity of $660 \mathrm{~m}^{3} / \mathrm{h}$. The regeneration procedure applied at Matla Power Station is illustrated in Table 2 and includes a description of process steps and the time required for each step. The mixed bed regeneration is excluded from the table because the profile was only done on the cation and anion resin regeneration.

\section{Methodology}

The following procedure was followed in creating regeneration profiles: 


\begin{tabular}{|l|l|}
\hline \multicolumn{2}{|c|}{ TABLE 3} \\
\multicolumn{2}{|c|}{ processes } \\
promical analysis on the various regeneration
\end{tabular}

- The demineralisation process is operated to maximum capacity. In this case the maximum capacity was determined by runlength and was set at $12000 \mathrm{~m}^{3}$. The run-length was based on conductivity and a safety margin was allowed.

- Water samples for the regeneration profiles were taken at exhaustion of the demineralisation run.

- Samples were taken at predetermined time intervals to carry out analysis on the different parameters. The time intervals varied from 1 to $2 \mathrm{~min}$ at the beginning of each regeneration step to 5 min later in the process.

- Chemical analysis was done according to Standard Methods, 1995.

- The analysis results were plotted as individual graphs.

- Regeneration profiles were analysed to identify possible shortcomings in the regeneration processes.

- Regeneration procedures were then adjusted to eliminate shortcomings.

The analyses done to determine the profiles are given in Table 3.

After making changes to the regeneration processes to eliminate shortcomings, a second profile was compiled to assess improvements to the regeneration processes. Based on the findings from the first regeneration run, the following changes were introduced to optimise the process steps. The reasons for the changes are discussed in the section on results and discussion.

\begin{tabular}{|l|c|c|c|}
\hline \multicolumn{4}{|c|}{ TABLE 4 } \\
Chemical analysis of demineraliser effluent before \\
regeneration of both \\
\hline Parameter & Units & Cation inlet & Cation inlet \\
2 July 2002 & 24 July 2002 \\
\hline Calcium hardness & $\mathrm{mg} / \mathrm{l}$ & 14 & 14 \\
Magnesium hardness & $\mathrm{mg} / \mathrm{l}$ & 21 & 24 \\
Total hardness & $\mathrm{mg} / \mathrm{l}$ & 35 & 38 \\
Sodium & $\mathrm{mg} / \mathrm{l}$ & 7.4 & 8.7 \\
Potassium & $\mathrm{mg} / \mathrm{l}$ & 2 & 2.7 \\
Chloride & $\mathrm{mg} / \mathrm{l}$ & 10 & 10.2 \\
Silica & $\mu \mathrm{g} / \mathrm{l}$ & 350 & 410 \\
Sulphate & $\mathrm{mg} / \mathrm{l}$ & 7.6 & 7.5 \\
\hline
\end{tabular}

\section{The cation resin regeneration changes are:}

For the $1^{\text {st }}$ acid injection step:

- The acid strength of $0.5 \%$ top injection $/ 2.0 \%$ bottom injection was changed to $0.7 \%$ top injection/2.0\% bottom injection.

- The injection time was decreased from 80 to $70 \mathrm{~min}$.

For the $2^{\text {nd }}$ acid injection step:

- The acid strength of $0.8 \%$ top injection $/ 3.0 \%$ bottom injection was changed to $0.7 \%$ top injection $/ 4.0 \%$ bottom injection.

- The injection time was increased from 20 to $30 \mathrm{~min}$.

Downward rinse: The rinsing time was increased from 30 to $35 \mathrm{~min}$.

\section{The anion resin regeneration changes are:}

On the $4 \%$ caustic injection to the strong base step:

- The strong base resin caustic injection time was increased from 50 to $60 \mathrm{~min}$.

- From the $40^{\text {th }}$ to the $50^{\text {th }}$ min in the injection step additional samples were taken every 2 min for silica analysis.

On the weak base caustic injection step:

- The injection time was increased from 30 to $40 \mathrm{~min}$.

\section{Results}

\section{Demineralisation plant chemical analysis}

Table 4 shows the analyses of the inlet to the cation exchanger before the first regeneration run (2 July 2002) and before the second regeneration run incorporating changes to optimise the process (24 July 2002).

Only cation and anion regeneration profiles were determined for the most important process steps. Steps 1, 2, and 3 of the cation regeneration and Steps 1(a), 2(a), and 1(b) of the anion regeneration were omitted (refer to Table 2). The profiles started with the $\mathrm{H}_{2} \mathrm{SO}_{4}$ injection for the cation and $\mathrm{NaOH}$ injection for the anion because the major changes take place during these steps. The cation and anion regeneration profiles done on 02 July 2002, are given in Figs. 1 to 3 and those done on 24 July 2002 are given in Figs. 4 to 6 . Table 3 gives the analysis results. The species loaded onto the resins during the service runs and removed during the regenerations are given in Table 5 . 
TABLE 5

Species loaded onto and removed from the resins during $1^{\text {st }}$ and $2^{\text {nd }}$ regeneration

\begin{tabular}{|c|c|c|c|c|c|c|c|c|}
\hline \multicolumn{9}{|l|}{ First regeneration } \\
\hline Volume treated $\mathrm{m}^{3}$ & $\begin{array}{c}\text { Tot } \mathrm{H}^{\star} \\
\mathrm{mg} / \mathrm{l} \text { as } \\
\mathrm{CaCO}_{3}\end{array}$ & $\begin{array}{c}\mathrm{Ca} \mathrm{H}^{*} \\
\mathrm{mg} / \mathrm{l} \text { as } \\
\mathrm{CaCO}_{3}\end{array}$ & $\begin{array}{c}\mathrm{Mg} \mathrm{H}^{*} \\
\mathrm{mg} / \mathrm{l} \text { as } \\
\mathrm{CaCO}_{3}\end{array}$ & $\begin{array}{l}\text { Sodium } \\
\mathrm{mg} / \mathrm{l} \text { as } \\
\mathrm{Na}^{+}\end{array}$ & $\begin{array}{c}\text { Potass } \\
\mathrm{mg} / \mathrm{l} \text { as } \\
\mathrm{K}^{+}\end{array}$ & $\begin{array}{l}\text { Chloride } \\
\mathrm{mg} / \mathrm{l} \text { as } \\
\mathrm{Cl}^{-}\end{array}$ & $\begin{array}{c}\text { Sulphate } \\
\mathrm{mg} / \mathrm{l} \text { as } \\
\mathrm{SO}_{4}^{2-}\end{array}$ & $\begin{array}{c}\text { Silica } \\
\mathrm{mg} / \mathrm{l} \text { as } \\
\mathrm{SiO}_{2}\end{array}$ \\
\hline 10704 & 35 & 14 & 21 & 7.4 & 2 & 10 & 7.6 & 0.35 \\
\hline kg loaded & 374.64 & 149.86 & 224.78 & 79.21 & 21.41 & 107.04 & 81.35 & 3.75 \\
\hline Removed & 333.68 & 131.48 & 202.20 & 70.81 & 18.92 & 103.19 & 65.47 & 8.73 \\
\hline \%removed & 89.1 & 87.7 & 90.0 & 89.4 & 88.4 & 96.41 & 80.5 & 233.1 \\
\hline \multicolumn{9}{|l|}{ Second regeneration } \\
\hline Volume treated $\mathrm{m}^{3}$ & $\begin{array}{c}\mathrm{Tot}^{*} \\
\mathrm{mg} / \mathrm{l} \text { as } \\
\mathrm{CaCO}_{3}\end{array}$ & $\begin{array}{c}\mathrm{Ca} \mathrm{H}^{*} \\
\mathrm{mg} / \mathrm{l} \text { as } \\
\mathrm{CaCO}_{3}\end{array}$ & $\begin{array}{c}\mathrm{Mg} \mathrm{H}^{*} \\
\mathrm{mg} / \mathrm{l} \text { as } \\
\mathrm{CaCO}_{3}\end{array}$ & $\begin{array}{l}\text { Sodium } \\
\mathrm{mg} / \mathrm{l} \text { as } \\
\mathrm{Na}^{+}\end{array}$ & $\begin{array}{c}\text { Potass } \\
\mathrm{mg} / \mathrm{l} \text { as } \\
\mathrm{K}^{+}\end{array}$ & $\begin{array}{c}\text { Chloride } \\
\mathrm{mg} / \mathrm{l} \text { as } \\
\mathrm{Cl}^{-}\end{array}$ & $\begin{array}{l}\text { Sulphate } \\
\mathrm{mg} / \mathrm{l} \text { as } \\
\mathrm{SO}_{4}^{2-}\end{array}$ & $\begin{array}{c}\text { Silica } \\
\mathrm{mg} / \mathrm{l} \text { as } \\
\mathrm{SiO}_{2}\end{array}$ \\
\hline 10340 & 38 & 14 & 24 & 8.7 & 2.7 & 10.2 & 7.5 & 0.41 \\
\hline kg loaded & 392.92 & 144.76 & 248.16 & 89.96 & 27.92 & 105.47 & 77.55 & 4.24 \\
\hline Removed & 360.24 & 131.22 & 229.01 & 81.12 & 25.84 & 94.86 & 64.76 & 6.50 \\
\hline$\%$ removed & 91.68 & 90.65 & 92.28 & 90.18 & 92.6 & 89.9 & 83.5 & 153.3 \\
\hline
\end{tabular}

\section{Discussion}

\section{Cation regeneration}

Table 6 shows the top and bottom acid injection strength during the two cation regeneration runs.

For the $1^{\text {st }}$ regeneration the top acid remained at $0.5 \%$ throughout the $1^{\text {st }}$ and $2^{\text {nd }}$ injection steps. It was supposed to remain at $0.5 \%$ for the $1^{\text {st }} 80 \mathrm{~min}$ and then increased to $0.8 \%$ for the last $20 \mathrm{~min}$ injection step according to prescribed procedures. The bottom acid remained at $2.5 \%$ for the entire $100 \mathrm{~min}$ but was supposed to increase from $2 \%\left(1^{\text {st }}\right.$ injection, $\left.80 \mathrm{~min}\right)$ to $3 \%\left(2^{\text {nd }}\right.$ injection, 20 $\min$ ).

For the $2^{\text {nd }}$ regeneration the top acid remained at $0.6 \%$ for the entire $100 \mathrm{~min}$. It was supposed to remain at $0.7 \%$ for the duration of the two injection steps. The bottom acid had an average strength of $2.6 \%$ during the $1^{\text {st }}$ injection step of $70 \mathrm{~min}$, but should have been $2 \%$. For the $2^{\text {nd }}$ injection step of $30 \mathrm{~min}$ the average strength was $3.1 \%$, which should have been $4 \%$. For optimisation purposes the top acid strength was changed from $0.5 \%$ ( $1^{\text {st }}$ injection) and $0.8 \%$ $\left(2^{\text {nd }}\right.$ injection) to $0.7 \%$ for the entire 100 min injection time. The bottom acid strength was changed from $2 \%\left(1^{\text {st }}\right.$ injection) and $3 \%$ $\left(2^{\text {nd }}\right.$ injection) to $2 \%\left(1^{\text {st }}\right.$ injection $)$ and $4 \%$ ( $2^{\text {nd }}$ injection $)$. The time for the $1^{\text {st }}$ injection was decreased from 80 to $70 \mathrm{~min}$ and increased for the $2^{\text {nd }}$ injection from 20 to $30 \mathrm{~min}$ for a total of $100 \mathrm{~min}$ injection time.

The reason for these changes was to remove as many of the hardness salts exchanged by the WAC resin as quickly as possible before the rinse steps. The acid strength increases had to be done manually during the $2^{\text {nd }}$ regeneration by either turning up the acid dosing pump stroke or reducing the dilution water flow. The existing system could not ensure automatic control of increased acid concentration. This caused the acid strengths to fluctuate. In both regenerations the effluent acid strengths started to increase in the $55^{\text {th }}$ min of the injection steps, indicating that most of the regeneration process was completed. This, however, was only true for calcium and magnesium.

\section{Calcium, magnesium, and total hardness removal}

Table 5 shows that more calcium and magnesium ions were loaded on to the resin during the $2^{\text {nd }}$ service run and also that more ions were removed during regeneration. This can be ascribed to the higher average top acid strength for the $2^{\text {nd }}$ regeneration of $0.6 \%$, against $0.5 \%$ for the $1^{\text {st }}$ regeneration. Figures 1 and 4 show that the top acid injection strength for both regenerations was never obtained and was, on average, lower than anticipated. This had the effect of insufficient removal of calcium and mgnesium ions. The dotted line on the total hardness graphs illustrates an assumption of what the removal would have been if the top acid strengths were correct.

\section{Sodium and potassium removal}

The SAC resin removes sodium and potassium ions. From Table 5 it can be seen that the removal percentage for sodium virtually remained the same for both regenerations at about $90 \%$. However, there was a marked difference in the case of potassium. During the second regeneration $92.6 \%$ was removed compared to $88.4 \%$ during the $1^{\text {st }}$ regeneration. Although the SAC resin has greater preference for sodium ions than for potassium ions, the preference for sodium release during the service run before potassium could clearly be seen on the two individual graphs. Unlike calcium and magnesium the bulk of the sodium and potassium ions was not removed during the acid injection phases but rather during the "Rinse Top and Bottom" step. The reason for this was that the bottom acid strength was never controlled at the specification values (see Table 6 ). The $2^{\text {nd }}$ injection bottom acid strength for both regenerations on average was lower than what was expected, that is $2.5 \%$ against $3 \%$ ( $1^{\text {st }}$ regeneration $)$ and $3.1 \%$ against $4 \%\left(2^{\text {nd }}\right.$ regeneration).

\section{Conductivity removal}

In order to reduce the conductivity of the effluent, the time for the downward rinse step was increased from 30 ( $1^{\text {st }}$ regeneration) to $35 \mathrm{~min}$ ( $2^{\text {nd }}$ regeneration $)$. During the first regeneration the conductivity was $1950 \mu \mathrm{S} / \mathrm{cm}$ after $30 \mathrm{~min}$, whereas during the second 
regeneration after 35 min it was 1550 $\mu \mathrm{S} / \mathrm{cm}$. In both cases it should have been below $200 \mu \mathrm{S} / \mathrm{cm}$. From the above it is obvious that more tests are needed to determine the correct rinse times.

\section{Anion regeneration}

The anion regeneration is done on the weak base and strong base resins in two separate vessels. Results are therefore discussed separately (Table 7).

First regeneration: Figs. 2 and 3 (2 July 2002)

The $\mathrm{NaOH}$ strength for the strong base regeneration average met the specification of $4.0 \%$, whereas the $\mathrm{NaOH}$ strength for the weak base regeneration was lower than the specified value of $4.0 \%$. Referring to Figs. $1(\mathrm{~b})$ and 1(c) it was evident that the injection times were too short because a large amount of ions were removed during the rinse steps instead of during the $\mathrm{NaOH}$ injection step.

\section{Second regeneration: Figs. 5 and 6 (24 July 2002)}

The injection times for the strong base regeneration steps were increased from 50 to $60 \mathrm{~min}$ ( $1^{\text {st }}$ injection) and 30 to $40 \mathrm{~min}$ ( $2^{\text {nd }}$ injection $)$. For the weak base regeneration the injection time was increased from 30 to $40 \mathrm{~min}$. The reason for this decision was to remove the majority of the ions during the injection phase.

\section{Chloride removal}

Table 5 shows that more chloride ions were loaded on to the anion resins during the $1^{\text {st }}$ service run than on to the $2^{\text {nd }}$. Also, more chloride was removed from the resin during the $1^{\text {st }}$ regeneration although the injection times were increased by a total of 20 min. Table 8 shows that when comparing the two regenerations, the SBA resin removed more chlorides during the $1^{\text {st }}$ regeneration than the $2^{\text {nd }}$. The opposite happened with the WBA resin, more chlorides were removed during the $2^{\text {nd }}$ regeneration.

This shows that the $2^{\text {nd }}$ weak base regeneration benefited more from the 10 min increase in injection time than the strong base with reference to \% removal vs. loading. This confirms the theory that chlorides are predominantly exchanged by the weak base resins.

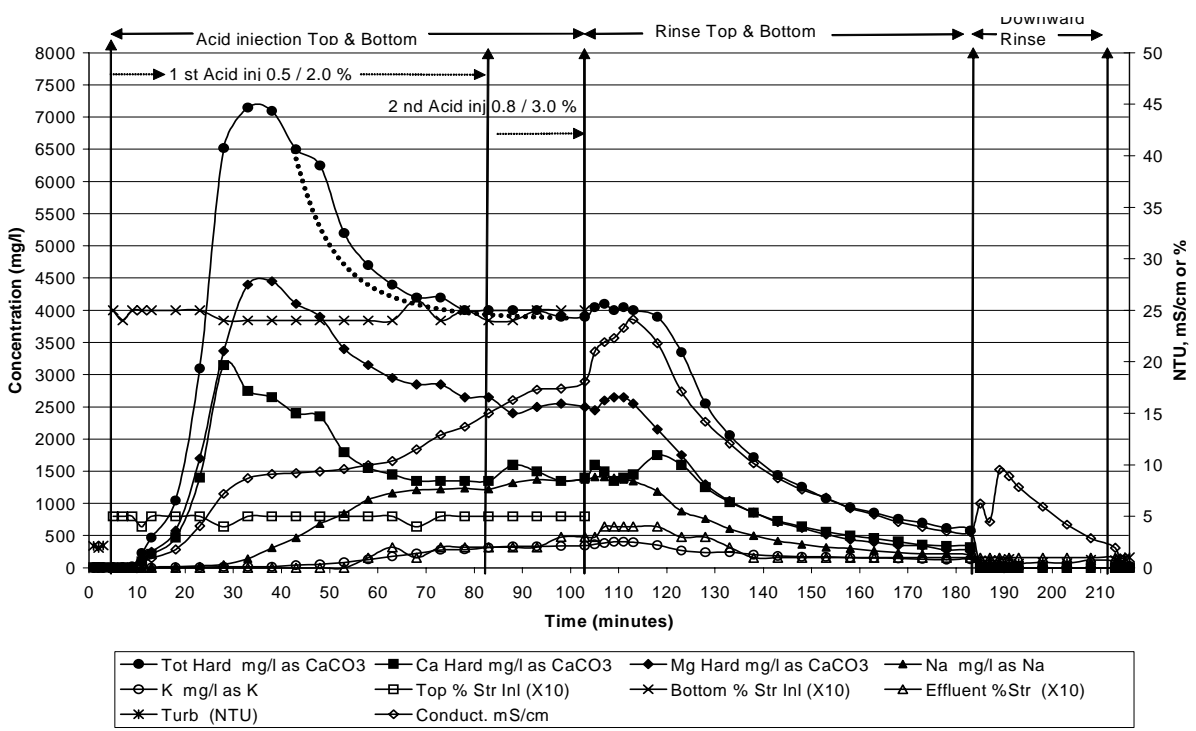

Figure 1

CATION 1 REGEN PROFILE - Major steps only - 2 July 2002

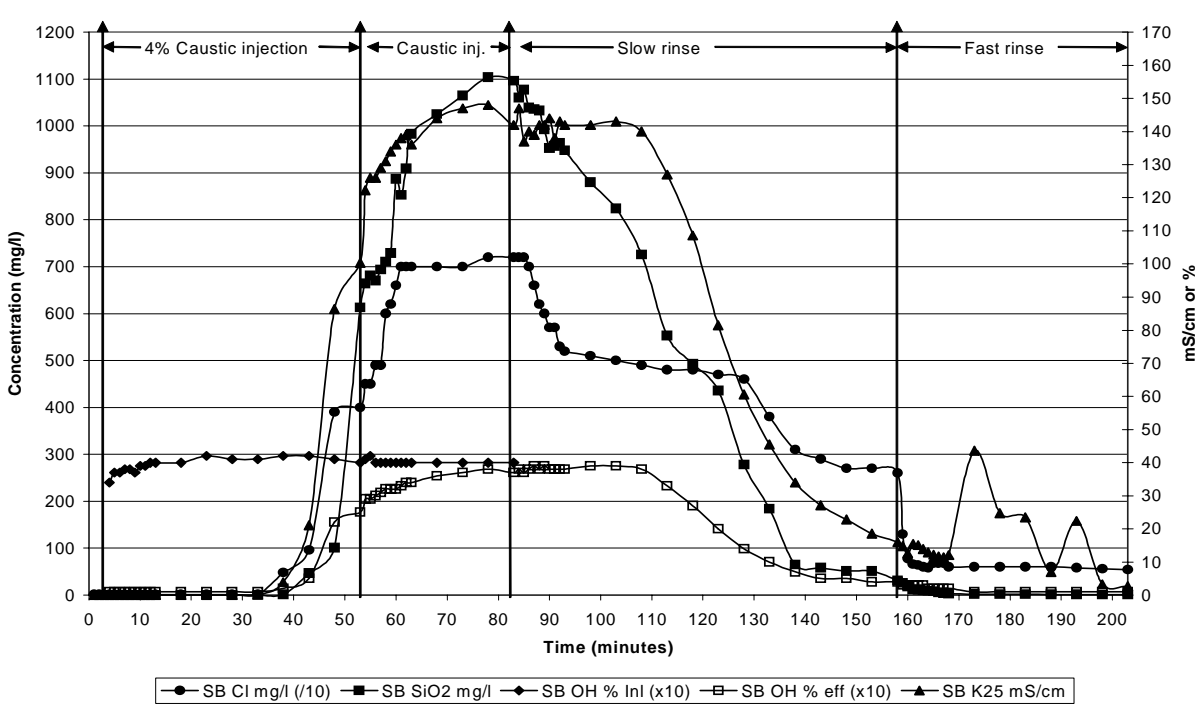

Figure 2

ANION 1 REGEN PROFILE - Strong Base - Major steps only - 2 July

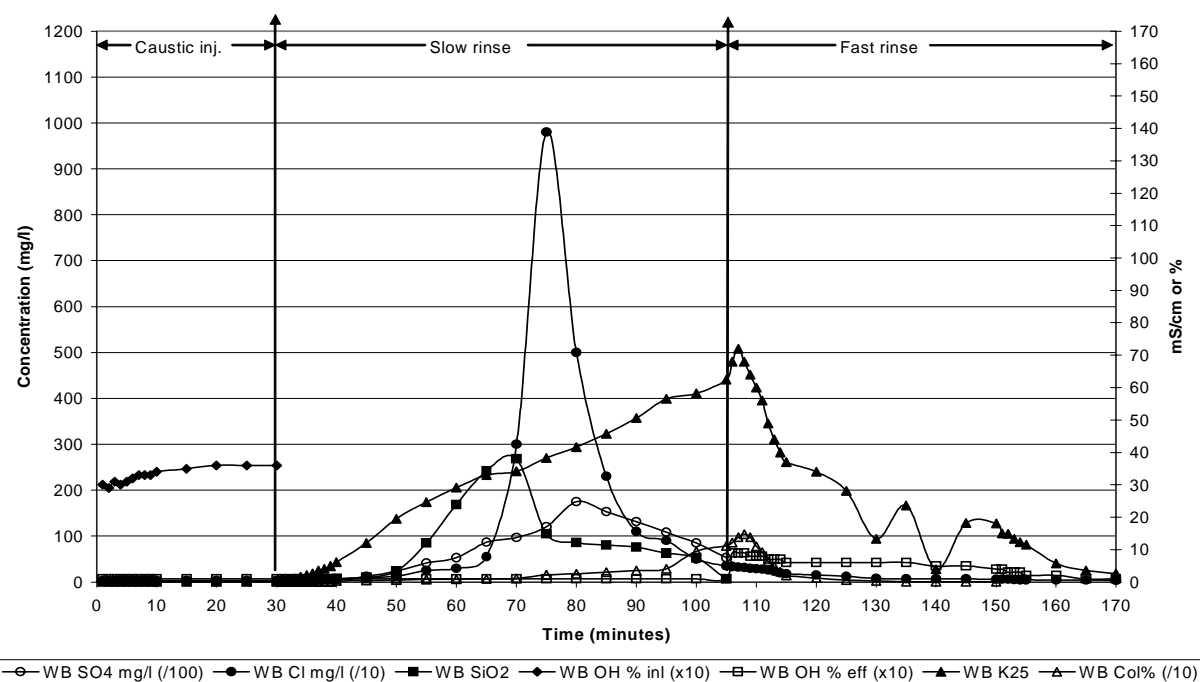

Figure 3

ANION 1 REGEN PROFILE - Weak Base - Major steps only - 2 July 2002 


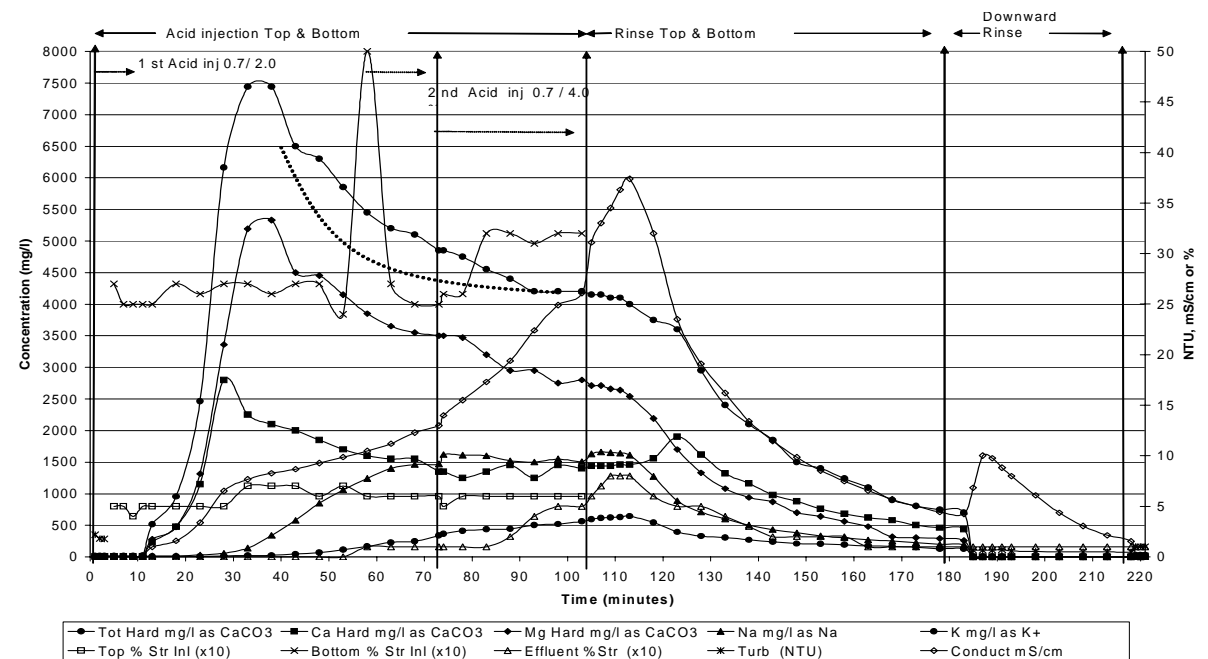

Figure 4

CATION 1 REGEN PROFILE - Major steps only - 24 July 2002

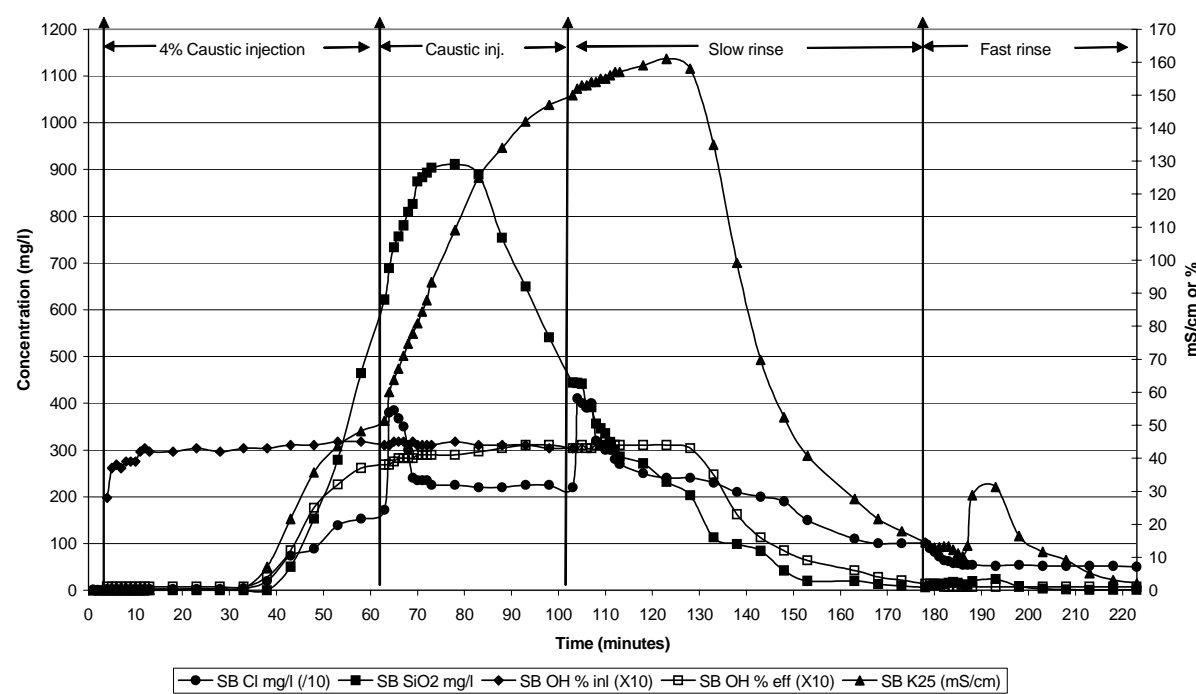

Figure 5

ANION 1 REGEN PROFILE - Strong Base Major steps only - 24 July 2002

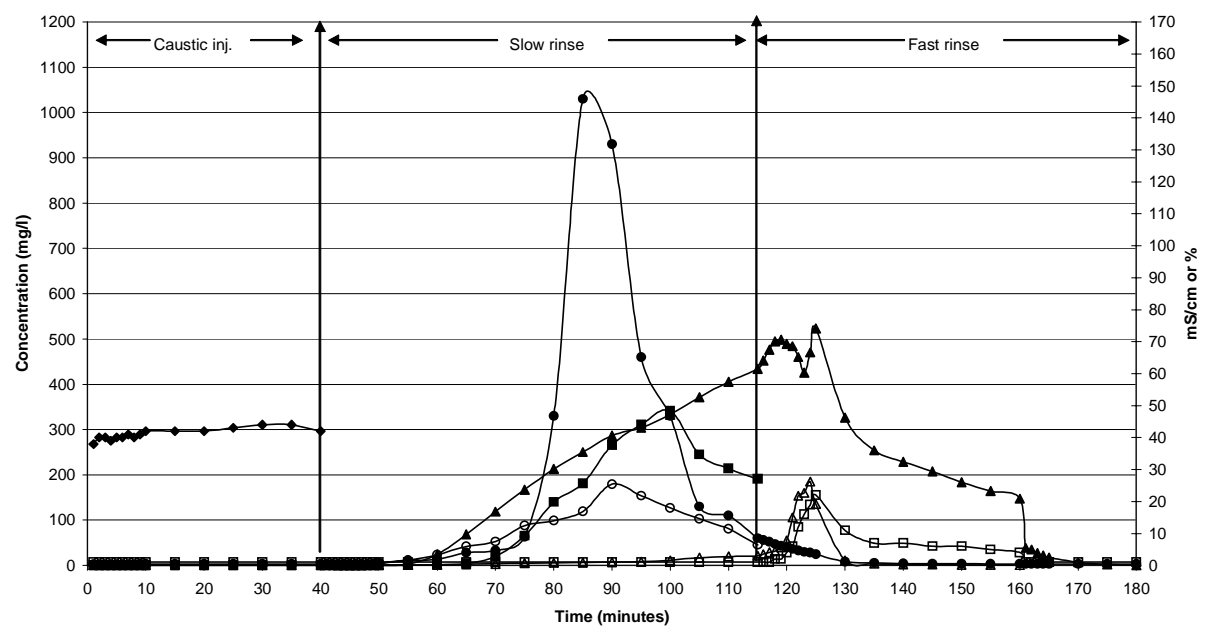

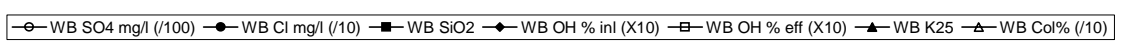

Figure 6

ANION 1 REGEN PROFILE - Weak Base Major steps only - 24 July 2002

\section{Silica removal}

Table 5 shows that more silica was removed than was loaded on the resin. When comparing Figs. 2 and 3 and Figs. 5 and 6 it appears that more silica was loaded from the strong base onto the weak base than was removed by the weak base during the rinse steps. When comparing loaded figures with removal figures, as indicated in Table 5, it is evident that the analysis could not be correct. Silica was determined colorimetrically on a spectrophotometer at wavelength $810 \mathrm{~nm}$. The following may be reasons why the analysis failed to give the correct concentrations:

- The sample was too alkaline in the case of the strong base regeneration and inadequate neutralisation was done. In the case of the weak base regeneration the sample was not as alkaline as in the case of the strong base.

- The dilution factor was too large, causing a significant error in the calculated values.

- Precipitation of silica before analysis could have taken place.

Silica determinations in high alkaline solutions should be further investigated for future regeneration profile compilation.

\section{Sulphate removal}

Table 5 indicates that more sulphates were removed during the $2^{\text {nd }}$ regeneration. This can be ascribed to the longer injection times during the $2^{\text {nd }}$ regeneration.

\section{Colour}

During the regeneration process a change in colour of the weak base effluent was evident. This colour change from clear to a dark toffee colour occurred during the initial stages of the fast rinse step due to the release of organic material from the ion-exchange resins.

To determine organic material of high concentrations, is very complex and difficult. Methods like Oxygen Absorbed (4 $\mathrm{h}$ method) and Total Organic Carbon (TOC) is available but in this case it was impractical to use it, because of the high concentrations encountered. It was decided to use the colour method to distinguish between different concentrations. The absorption taken up 


\begin{tabular}{|c|c|c|c|c|c|c|}
\hline \multicolumn{7}{|c|}{$\begin{array}{c}\text { TABLE } 6 \\
\text { Top and bottom acid injection strengths during cation regeneration }\end{array}$} \\
\hline & \multicolumn{3}{|c|}{$1^{\text {st }}$ Regeneration } & \multicolumn{3}{|c|}{$2^{\text {nd }}$ Regeneration } \\
\hline & $\begin{array}{l}\text { Top } \\
\text { Acid \% }\end{array}$ & $\begin{array}{l}\text { Bottom } \\
\text { Acid \% }\end{array}$ & $\begin{array}{c}\text { Time } \\
\text { Min }\end{array}$ & $\begin{array}{l}\text { Top } \\
\text { Acid \% }\end{array}$ & $\begin{array}{l}\text { Bottom } \\
\text { Acid \% }\end{array}$ & $\begin{array}{c}\text { Time } \\
\text { Min }\end{array}$ \\
\hline $1^{\text {st }}$ Injection & 0.5 & 2.5 & 80 & 0.6 & 2.6 & 70 \\
\hline Specification & 0.5 & 2.0 & 80 & 0.7 & 2.0 & 70 \\
\hline $2^{\text {nd }}$ Injection & 0.5 & 2.5 & 20 & 0.6 & 3.1 & 30 \\
\hline Specification & 0.8 & 2.0 & 20 & 0.7 & 4.0 & 30 \\
\hline
\end{tabular}

\begin{tabular}{|c|c|c|c|c|}
\hline \multicolumn{5}{|c|}{$\begin{array}{c}\text { TABLE } 7 \\
\text { NaOH injection strengths during } 1^{\text {st }} \text { and } 2^{\text {nd }} \text { regenerations }\end{array}$} \\
\hline & \multicolumn{2}{|c|}{$1^{\text {st }}$ Regeneration } & \multicolumn{2}{|c|}{$2^{\text {nd }}$ Regeneration } \\
\hline & $\mathrm{NaOH} \%$ & Time Min & $\mathrm{NaOH} \%$ & Time Min \\
\hline $\begin{array}{l}\text { Injection to strong base only } \\
\text { Specification }\end{array}$ & $\begin{array}{c}3.4-4.2 \\
4.0\end{array}$ & $\begin{array}{l}50 \\
50\end{array}$ & $\begin{array}{c}2.8-4.5 \\
4.0\end{array}$ & $\begin{array}{l}60 \\
60\end{array}$ \\
\hline $\begin{array}{l}\text { Injection to strong base and weak base* } \\
\text { Specification }\end{array}$ & 4.04 .0 & 3030 & 4.44 .0 & 4040 \\
\hline $\begin{array}{l}\text { Injection to strong base and weak base** } \\
\text { Specification }\end{array}$ & $\begin{array}{c}2.9-3.6 \\
4.0\end{array}$ & $\begin{array}{l}30 \\
30\end{array}$ & $\begin{array}{c}3.8-4.4 \\
4.0\end{array}$ & $\begin{array}{l}40 \\
40\end{array}$ \\
\hline
\end{tabular}

by each sample was measured on a spectrophotometer at wavelength $425 \mathrm{~nm}$. A graph, absorbance on the y-axis against percentage on the $\mathrm{x}$-axis, was drawn up. Absorbance of 1.0 was taken as $100 \%$ and a straight line graph was obtained. The concentration of each sample was read from the graph. In cases where the sample had a colour greater than the absorbance of 1.0 the sample was diluted. More organic material was removed by the WBA resins during the $2^{\text {nd }}$ regeneration than during the $1^{\text {st }}$. This increase was most probably due to the longer injection times during the $2^{\text {nd }}$ regeneration (refer Table 5).

\section{Conductivity}

The conductivity appeared very erratic during the fast rinse step (Figs. 2 and 5). This was due to changes in flow direction through the weak base resin.

\section{Recommendations}

The research indicated a number of changes that could be made to the plant and process to improve the overall regeneration process and/or to obtain longer run lengths. These are:

\section{Cation regeneration}

Modify the existing top and bottom acid injection step To control the acid strengths an automated system should be installed. During the project it was proved that manual acid operations were risky and control was poor. This can result in calcium sulphate precipitation on the cation resins. It is also recommended that demineralised water instead of filtered water be used as dilution water for both top and bottom acid injections.

\section{TABLE 8}

Chloride removal by strong and weak base resins during the two regenerations

\begin{tabular}{|l|c|c|c|}
\hline & $\begin{array}{c}\text { Total } \\
\text { chloride } \\
\text { removal }\end{array}$ & $\begin{array}{c}\text { Strong } \\
\text { base } \\
\text { chloride } \\
\text { removal }\end{array}$ & $\begin{array}{c}\text { Weak } \\
\text { base } \\
\text { chloride } \\
\text { removal }\end{array}$ \\
\hline First regeneration & $103.19 \mathrm{~kg}$ & $85.83 \mathrm{~kg}$ & $17.36 \mathrm{~kg}$ \\
\hline Second regeneration & $94.86 \mathrm{~kg}$ & $71.31 \mathrm{~kg}$ & $23.55 \mathrm{~kg}$ \\
\hline
\end{tabular}

\section{Increase acid injection strengths}

For the $2^{\text {nd }}$ regeneration the acid strengths for both top and bottom injections were adjusted from $0.5 \% / 2.0 \%$ ( $1^{\text {st }}$ injection) and $0.8 \% / 3.0 \%$ ( $2^{\text {nd }}$ injection) to $0.7 \% / 2.0 \%$ and $0.7 / 4.0 \%$ (see Table 6 ) respectively. It is recommended that the adjusted acid strengths be used since it is evident from Table 5 that more species were removed during the $2^{\text {nd }}$ regeneration.

\section{Decrease the time for the $1^{\text {st }}$ acid injection and increase it for the $2^{\text {nd }}$}

It is recommended that the time for the $1^{\text {st }}$ acid injection be reduced from 80 to $70 \mathrm{~min}$ and the time for the $2^{\text {nd }}$ acid injection be increased from 20 to $30 \mathrm{~min}$. The total injection time should remain at 100 $\mathrm{min}$. The aim of this change is to remove more species from the resins during the regeneration step and not allowing this to happen in the rinse steps. 


\section{Anion regeneration}

\section{Increase the strong base $\mathrm{NaOH}$ injection time in both} injection steps

It is recommended that the injection time be increased from 50 to $60 \mathrm{~min}$ for the strong base regeneration, and from 30 to $40 \mathrm{~min}$ for the strong base/weak base parallel injection. The total injection time for the strong base was increased from 80 to $100 \mathrm{~min}$. The reason for this change was to remove as much silica and chloride as possible during the injection steps and not during the rinse steps.

\section{Conclusions}

Conclusions that can be made from the study of the regeneration profiles are that longer injection times for both the cation and anion regenerations are needed for better removal of most of the species. The study indicated that a large portion of species removal is obtained from the rinse steps.

Regeneration profiles are the 'fingerprints' of the demineralisation process. By analysing the fingerprints, inefficiencies can be eliminated and unnecessary costs and time delays can be avoided. The studies showed that regeneration profiles can be used effectively to identify plant and process problems and therefore to optimise the process.

It is recommended that regeneration profiles be done on an annual basis on all demineralisation trains. As experience grows it might not be necessary to analyse for the full extent of the regeneration process and for all parameters.

\section{Acknowledgments}

The authors acknowledge the support and data provided by the Utilities Department at the Matla Power Station owned by Eskom Pty (Ltd) and to Mpho Manamela who assisted in the laboratory work.

\section{References}

DREW (1994) Principles of Industrial Water Treatment. Drew Industrial Division, Boonton, New Jersey.

ESKOM (2001) Chemistry Standard for Coal Fired Units with Drum Boilers Operating at $17 \mathrm{MPa}$ and Above. Eskom, Johannesburg.

FOSTER WHEELER DELTA COCHRANE (1978) Operation Manual for Foster Wheeler Delta Cochrane Process Water Treatment Complex for Matla South Power Station - Vol. 2. Eskom, Johannesburg

FREDERICK K (1996) Countercurrent regeneration: Principles and Applications. Ultrapure Water (Jul/Aug) 53-56.

HARFST WF (1993) Improved feedwater quality enhances boiler operation. Ultrapure Water (Feb) 34-37.

MEYERS P (1996) Demineraliser design considerations-Part 2. Ultrapure Water (Oct) 17-22.

MODERN POWER STATION PRACTICE (3rd edn.) (1992) Chemistry and Metallurgy - Vol. E. Pergamon Press, New York. 37-43.

STANDARD METHODS (1995) Standard Methods for the Examination of Water and Wastewater (19th edn.) Joint Ed. Board: Eaton AD, Clesceri LS and Greenberg AE. APHA-AWWA-WPCF. United Book Press, Inc., Baltimore, Maryland. 